\title{
BANKRUPTCY AND REORGANIZATION: A SURVEY OF CHANGES. III*
}

\author{
Edward H. Levi and Jaries War. Moore $\dagger$
}

NON-STATOTORY CHANGES DURING THE DEPRESSION

\section{J} UDICIAL opposition to the consent receivership, apparent in I928, increased. In $\mathrm{I}_{932}$, in Michigan v. Michigan Trust Co., ${ }^{283}$ the question before the Supreme Court was whether state taxes should have priority over claims of creditors to the proceeds of an equity receivership sale. The court held the taxes were payable before creditors' claims, and in an opinion written by Justice Cardozo took occasion to refer again to the abuses of the consent receivership. He stated that the court has "had occasion to point out the abuses that can arise from friendly receiverships forestalling the normal processes of administration in bankruptcy and enabling a tottering business to continue while creditors are held at bay." In Shapiro v. Wilgus, ${ }^{284}$ an individual debtor incorporated in order to avoid the rule that an individual debtor could not consent to a receivership, and then three days later went into a consent receivership as a corporation. The Supreme Court allowed a judgment creditor to levy execution on property in the hands of the federal receiver, stating: "True indeed it is that receivers have at times been appointed even by the federal courts at the suit of simple contract creditors if the defendant was willing to waive the irregularity and to consent to the decree. . . We have given warning more than once, however, that the remedy in such circumstances is not to be granted loosely, but is to be watched with jealous eyes." ${ }^{285}$ The attitude of the Supreme Court in this case is to be compared with the holding of a federal district court that a debtor may incorporate itself and proceed in good faith under section $77 \mathrm{B.}{ }^{286}$

Judicial distemper against the consent receivership reached its height

* Prepared, together with articles published in the December and February issues of this Review, by the authors for the International Academy of Comparative Law, The Hague, as reporters on the liquidation and reorganization legislation of England, Canada, and the United States. The previous articles dealt with the English and Canadian history and experience in this field, the early American bankruptcy legislation, and statutory changes during the depression.

$\dagger$ Assistant Professors of Law, University of Chicago Law School.

283286 U.S. 334 (I932).

284287 U.S. 348 (I932).

${ }^{285} 287$ U.S. 348,356 (1932).

${ }^{286}$ See page 246 silpra. 
in the May Hosiery Mills case. ${ }^{287}$ The F. \&. W. Grand 5-ro-25 cent stores was in consent receivership in the Southern District of New York. There were twenty-eight ancillary receiverships throughout the country. The reorganizers hit a snag in the district court of Montana. The court not only refused to appoint a consent receiver but held the attorneys in contempt for applying for a receiver. The language of the court was not temperate. Among a great many other things it said:

"That New York counsel are leaders and of Who's Who is of course. The experience, skill, finesse, effrontery, prestige, and impressive personality of counsel of that rank were necessary to devise the plan and program and to impose it upon courts. Unethical practice is by no means limited to the lesser of the bar. It is ventured that the most subtle and effective ambulance chasers operate on golf links, in the club, at the poker table, behind a smoke screen of claim agents, and in collusion with banks and trust companies who are the ostensible advertisers for business the profit of which is divided. Moreover, like Western Chinamen, all counsel should look alike, in court at least." ${ }^{288}$ On appeal the contempt holdings were reversed. ${ }^{289}$ The dismissal of the creditor's bill was by that time moot since the debtor was in bankruptcy. But the air was not particularly clear.

Finally in First National Bank v. Flershem, ${ }^{290}$ the Supreme Court tackled the problem of whether an equity receivership could be resorted to as a means of reorganizing solvent corporations. The National Radiator Corporation which had been losing money, but whose ratio of current assets to current liabilities was more than ten to one, and whose ratio of cash on hand to all current liabilities was three and one half to one, felt that it would be economically wise to reduce its liability on debentures. Accordingly a plan was prepared which involved the creation of a new corporation and the substitution of income debentures and stock for the present debentures, which had a sinking fund requirement. In order to prevent action by dissenting debenture holders, the old corporation went into receivership on a petition by the co-operating debenture holders' committee. The trustee for the debenture holders intervened and proceeded as the plaintiff in the receivership proceedings. A judicial sale to the new corporation at a low upset price was then confirmed. On

${ }^{287}$ May Hosiery Mills, Inc. v. F. W. Grand 5-ro-25 Cent Stores, Inc., 59 F. (2d) 218 (D.Mont. 1932).

${ }^{288} 59$ F. (2d) 218, 222 (D.Mont. I932). $\quad{ }^{289} 64$ F. (2d) 450 (C.C.A. 9th I933).

${ }^{290} 290$ U.S. 504 (1934). For a good comment on this case see I Univ. Chi. L. Rev. 805 (1934). 
appeal, Justice Brandeis held that the dissenting debenture holders were entitled to be paid in full, and that the receivership was improper. Although he pointed out not only the lack of insolvency in either the bankruptcy or equity sense and the presence of sufficient cash for current operations, in a footnote to the case he sought to limit the use of the receivership as a reorganization device to railroads and other public utilities. ${ }^{29 x}$ Thus the case, though distinguishable on its facts, cast serious doubt not only on the propriety of receiverships for solvent corporations with inadequate funds, but on the use of receiverships for the reorganization of all industrials.

Meanwhile some of the lower federal courts had perfected a rationale for the consent receivership itself which apparently has survived the depression as a rule of thumb. Judge Augustus Hand in Kingsport Press v. Brief English Systems ${ }^{292}$ laid down two elements which would be important in determining the propriety of the receivership: (I) Did creditors need the receivership so that they would get paid and avoid preferences; (2) Is the objection to the receivership made seasonably. A third possible element was: Is bankruptcy available. Judge Learned Hand made a similar statement in Ex parte Relmar Holding Co. ${ }^{293}$ Judge Evans added the requirement that there must be full disclosure to the court of the relationship between the debtor and creditors and the recommended receiver. He pointed out that the difficulty was not with the "consent receivership" but with a "friendly receiver." 294 And to calm the fears of reorganizers who were still involved in equity receiverships, Judge Woolsey in In re Paramount Publix Corp. ${ }^{295}$ stated "The familiar cry of collusion in a consent receivership is advanced here, but, as usual, it had not any merit." ${ }^{296}$

The federal courts had developed the devices of a hearing on the foreclosure decree, an upset price, hearing on the date for a sale, and on the confirmation of the sale, as a means of controlling, to some extent, reorganizations before them. The state courts had been more reluctant to develop their equity jurisprudence. The passage of federal reorganization laws threatened to put all reorganizations of any importance into federal courts. The federal courts commented on the defects in the state court's procedure. One federal court spoke of "The state courts being somewhat restricted in making effective proposed reorganization when confronted

${ }^{29 x} I d$. at $5^{1} 5$, note 7 .

${ }_{292} 54$ F. (2d) 497 (C.C.A. $2 d$ r93I). $\quad 2936$ I F. (2d) 94 I (C.C.A. 2d r932).

${ }_{294}$ In re Insull Utility Investments, 6 F. Supp. 653 (N.D. Ill. 1933), aff'd in 74 F. (2d) 5 ro (C.C.A. $7^{\text {th }}$ I935).

${ }^{295}$ Io F. Supp. 504 (S.D.N.Y. I934). $\quad{ }^{296} I d$. at 508. 
by minority opposition."'297 This declaration brought the response from the state court that "equity powers of State courts are no more limited than those of Federal courts." ${ }^{298}$ Jealousy made for progress.

Indeed the early emergency days of the depression saw some of the state courts going farther than the federal courts ever had gone, and taking a position from which the state courts themselves have since receded. In Suring v. Giese, ${ }^{299}$ the Wisconsin court affirmed a decree which confirmed a sale on condition that the plaintiff be denied a deficiency judgment. The court spoke approvingly of the power to refuse to confirm a sale altogether, when inadequacy of the price is coupled with an emergency, such as the economic crisis, which prevents competitive bidding. It also spoke approvingly of the power to set an upset price and elsewhere in the opinion stated that "future or potential value ... may legitimately be taken into account." The Circuit Court of Cook County went even further and expressly forbade the mortgagee from foreclosing until economic conditions changed. ${ }^{300}$ In a somewhat less radical case, the New York Supreme Court of Chautauqua County set an upset price for the protection of guarantors; it stressed abnormal conditions as the justification for the exercise of the power. ${ }^{30 x}$ The New Jersey courts in the early days of the depression went far towards withholding confirmation until the fair value was credited on the decree, remarking that "such a sale is no longer of any protection to the mortgagor. His shield has been converted into a sword to be used against him." ${ }_{302}$

These were innovating cases for the state courts in that they recognized that the devices of refusal to confirm and the upset price might be used by them. But they were more radical in their use of the economic crisis as the reason for refusal to confirm or for setting an upset price. And the implication of the Giese case was that the fair value which would be required was not the fair value during depression times, but under normal conditions. Such a doctrine was clearly only an emergency doctrine. These courts soon receded to the position that if the bid were fair under the state of the market at the time the bid was made then the sale would

${ }^{297}$ In re Knickerbocker Hotel Co., 8I F. (2d) 98I (C.C.A. 7th r936).

${ }^{298}$ Levy v. Broadway-Carmen Bldg. Corp., 366 IIl. 279 (1937).

299 210 Wis. 489 , 246 N.W. 556 (1933).

${ }^{300}$ First Union Trust and Savings Bank v. Division State Bank, Circuit Court of Cook County, General Number B 262438, April I, I933.

${ }^{305}$ Farmers' \& Mechanics Bank v. Eagle Bldg. Co., 15 I Misc. 249, 27 I N.Y.S. 306 (I934).

${ }^{302}$ Federal Title \& Mortgage Guaranty Co. v. Lowenstein, Ir3 N.J. Eq. 200, x66 Atl. 538 (r933). 
have to be confirmed. The Wisconsin court receded in Kremer v. Rule $e^{303}$ and Weiner v. Uthus. ${ }^{304}$ In the first case it refused to consider the market value of the premises at some remote time in the past, and said that it was looking for real value at the time of the sale. In the latter case the court remarked that "an emergency is not a fairly permanent condition of affairs", and held that a bid should be confirmed when it is not so low as to shock the conscience of the chancellor, and "only represents a disagreement as to present value." The Illinois Appellate Court ${ }^{305}$ reversed the extremely radical decision of the Cook County chancellor to forbid foreclosure until economic conditions changed. The New York courts, after establishing their inherent right to refuse confirmation, stated that all that was desired was a normal bid under the conditions then prevailing. ${ }^{306}$ The idea of a general court-imposed moratorium was disavowed; "to this court the sleeping of causes is as unthinkable as the sleeping of judges." 307 The New Jersey court denied that the depression was any defense to stay a foreclosure action. ${ }^{308}$

But the importance of these early decisions should not be denied. At the beginning of the depression the Illinois Supreme Court had said that the chancellor had no power to fix an upset price. ${ }^{309}$ At the end of the depression the same court announced with considerable eloquence that the inherent power of the court of equity was such that the chancellor in the proper exercise of his discretion could set an upset price..$^{350}$ The practice of the state courts in debtor relief cases had its effect on the creditor relief situation. The example of federal legislation and the jealousy of the state courts towards the federal courts were contributing factors. Thus the Illinois court in 1936 for the first time recognized that it had jurisdiction over the plan of reorganization. ${ }^{\text {IIx }}$ It recognized that it was impossible to determine whether the bid of the majority committee was fair without first determining whether the plan offered to security holders by the committee was fair.

The court's jurisdiction over the plan thus came to be recognized in

${ }^{303} 216$ Wis. 33I, 257 N.W. $x 66$ (1934). 304217 Wis. 56,258 N.W. $35^{8}$ (1935).

${ }^{305}$ First Union Trust \& Savings Bank v. Division State Bank, 272 Ill. App. 487 (I933). ${ }^{305}$ Monaghan v. May, 242 App. Div. 64, 273 N.Y.S. 475 (1934).

${ }^{307}$ Loma Holding Corp. v. Cripple Bush Corp., r47 Misc. 655, 265 N.Y.S. I25 (1933). ${ }^{308}$ Marneil Realty Corp. v. Twin Brook Realty Corp., Irg N.J.L. 205, I79 Atl. I10 (1935). ${ }^{309}$ Chicago Title \& Trust Co. v. Robin, 36I Ill. 26I, r98 N.E. 4 (r935).

${ }^{3 x 0}$ Levy v. Broadway-Carmen, 366 Ill. 279, 8 N.E. (2d) 67I (I937). 3xx First National Bank v. Bryn Mawr Bldg. Corp., 365 Ill. 409, 6 N.J. (2d) 654 (I937). 
the state courts. While the more standard practice was for a majority or minority committee to intervene in the receivership and ask the court to pass on the plan, collateral attack was also allowed through an application in an independent proceeding for a restraining order to prevent the majority committee from consummating an allegedly unfair plan..$^{32}$ One New York decision, later reversed, went to the extent of removing the members of a bondholders' committee. ${ }^{313}$ An aid to the court's jurisdiction was the desire of reorganizers to gain preliminary approval of the terms upon which certificates of deposit were to be issued, in order to gain exemption from registration of the certificates under the Securities Act. ${ }^{3 \times 4}$ Another factor was that when a house of issue was in receivership the court gained control over the lists of security holders which the house had. When these lists were of security holders of other debtors in reorganization, the court could deny or grant access to these lists as a means of preferring or discouraging plans of reorganization of the other debtors, and thus exercise indirect control over them..$^{355}$ Judge Mack similarly used his position to gain the organization of bondholders' committees, which would be willing to submit disputes to impartial arbiters, the consent of the arbiter to be required before any action possibly detrimental to security holders could be taken..$^{36}$

A depression phenomenon was the renewed interest in trustee purchase. Many trust indentures give the trustee under the indenture power to purchase at the foreclosure sale for the benefit of all bondholders. Under these circumstances the trustee will not be required to pay cash save for the expenses of the sale, and any claims prior to those of the bondholders. There can be no dissenters. Trustee purchase, when allowed, was one way through which the court could gain jurisdiction of the plan. The trustee holding the property for all the bondholders would be under the power of the court. The property could be operated during this period by the trustee, and a plan of reorganization could be worked out under the supervision of the court. It was extremely questionable whether a trustee might purchase, however, if there were no express provision in the inden-

${ }^{3 r 2}$ Bergelt v. Roberts, $25^{8}$ N.Y.S. 905, $25^{8}$ N.Y.S. 1086 (1932); see also Rice v. Pounds, 274 N.Y.S. 637 (I934).

${ }^{3 x_{3}}$ Harrigan v. Pounds, ${ }_{47}$ Misc. 666, reversed in 265 N.Y.S. 676 (1933).

${ }^{314}$ See Fortas, The Securities Act and Corporate Reorganization, 4 Law and Contemporary Problems 218 (1937).

3rs See Clinton Trust Co. v. I42-I44 Joralemon St. Corp., 269 N.Y.S. 437 (I934).

${ }^{356}$ See Report of the Securities and Exchange Commission, Part III, Committees for the Holders of Real Estate Bonds, appendix B (I936). 
ture giving him the power to do so. The Pennsylvania court in the classic case of Nay Aug Lumber Co. v. Scranton Trust Company, held that the power to purchase might be implied;317 but the case was not followed in most jurisdictions. ${ }^{3 \times 8}$ And no court had ever held that the trustee, in the absence of a direction from the court, would be under a duty to purchase. But the Illinois Appellate Court in Straus v. Chicago Title and Trust Company not only held that the trustee might be ordered to purchase, but said that he had an implied duty to do so. ${ }^{3 x}$ If the Straus case had remained as the law of the state, it would have upset reorganization practice completely, since committees, which had worked out plans of reorganization, would have no assurance that the trustee and the court would use that plan; nor would it be clear that committees under such circumstances would receive fees or expenses for the work they had done. In effect the Straus case was later overruled, although the court attempted to distinguish it on the basis that in the Straus case the indenture specifically gave the trustee the power to purchase..$^{320}$ The development of the court's jurisdiction over the plan made trustee-purchase less important, and it was not a vital issue during the last stages of the depression.

The last days of the depression indicated that trustees under indentures and committee members might be held to greater liability than they had been in the past. ${ }^{32 x}$ Both trustees and committee members have insulated themselves in the past by broad exculpatory provisions. These provisions were usually effective. ${ }^{322}$ But the impact of legislation and the general reform movement is such that trustees who authorize the substitution of worthless securities, ${ }^{323}$ or who collect their own debts ahead of the debts of the security holders ${ }^{324}$ may well be held liable in the future. The indication is clear, also, that committee members who buy securities from bondholders on the basis of special undisclosed knowledge may be held liable. ${ }^{325}$

${ }_{317} 240$ Pa. 500, 87 Atl. 843 (I9r3).

${ }^{338}$ See Werner, Harris \& Buck v. Equitable Trust Co., 85 F. (2d) 513 (C.C.A. Ioth I929). ${ }^{319} 273$ TIl. App. 63 (I933).

${ }^{320}$ Chicago Title and Trust Co. v. Robin, 36I Ill. 26x (1935); Chicago Title and Trust Co. v. Bamburg, 36r Mll. 29r (1935).

${ }^{22 x}$ Hazzard v. Chasé National Bank, I59 Misc. 57,287 N.Y.S. 54 I (I936); Starr v. Chase National Bank, N.Y. L. J. Sept. 21, 1936, p. 771, col. 6; First Trust Co. of Lincoln, Neb. v. Ricketts, 75 F. (2d) 309 (C.C.A. 8th T934).

${ }^{322}$ See Posner, Liability of the Trustee under the Trust Indenture, 42 Harv. L. Rev. I 98 (I928).

${ }^{323}$ The Hazzard case, note $3^{21}$ supra.

324 The Starr case, note 32 I supra.

${ }^{225}$ Nichol v. Sensenbrenner, 220 Wis. I65, 263 N.W. 650 (I935). 


\section{THE EVILS OF REORGANIZATION; PROPOSED} FEDERAL IEGISLATION

The problem of reorganization is primarily a problem of how a failing debtor may be made economically sound and at the same time the rights, insofar as they exist, of the creditors and stockholders be preserved under a fair arrangement. The result of a reorganization then should be a plan which is both fair and economically sound. If the final plan is not fair, there is less justification for preventing individual creditors from gaining preferences for themselves by their separate attacks upon the property. If the plan is not economically sound, the plan will be short lived; the evils which were at work to cause the old failure continue at work to cause a recurrence. In the United States, the problem of reorganization was not always recognized in the terms we have just stated. The history of the equity receivership as applied to reorganization was, for much of the time, the history of receiverships and foreclosures leading to supposedly fair judicial sales. But the symbols finally molded themselves, so that whatever usefulness they had lay in their flexibility as devices in the hands of a court, which wished to guide the reorganization into a fair and economically sound plan.

The problem of course has many aspects. At the outset reorganizers were faced with the difficulty of gaining a single forum in which the reorganization might be carried out. Equity receiverships required ancillary receiverships in every jurisdiction where the debtor had property. In bankruptcy proceedings, the separate ancillary proceedings followed as of course, ${ }^{326}$ but were nevertheless necessary, and the court had summary jurisdiction only over property of the debtor which was in the debtor's possession. The federal reorganization statutes have supplied the remedy. Indeed, they may have gone too far, because the control of the reorganization court today is so great that there may be statutory power which would authorize the trial of in personam actions in the reorganization court at great expense and inconvenience to third persons. ${ }^{327}$ Reorganizers were also confronted with the problem of gaining a binding adjudication as to the reorganization which they had perfected. This difficulty had never been completely vanquished. The reorganization statutes, however, give the court the jurisdiction to effect a binding decree on the accepted plan. Thus the reorganizers' problem as to a forum in which re-

$326 \S 2$ (20) of Bankr. Act.

${ }^{327}$ See Thomas v. Winslow, II F. Supp. 839 (N.Y. I935); but see Foust v. Munson Steamship Lines, 57 S. Ct. $9 \circ$ (1936). 
organization may be completed finally and in one proceeding has been solved.

Probably the most pressing problem which confronted reorganizers was the necessity under the reorganization law in the United States to pay cash to the dissenters. This leads to several difficulties. In the first place there was the theoretical difficulty of determining how much a dissenter should get before the sale would be fair. In the second place there was the practical difficulty that if the dissenter were to get too much, the reorganization might be impossible, and the position of the dissenters in reorganizations generally would become so attractive that future reorganizations be blocked. And in the third place this increased the necessity to raise cash, which in turn made the position of the stockholder who was willing to contribute cash much more important. The federal reorganization statutes have removed the necessity to pay cash to dissenters. If the dissenters represent more than one-third of a class, it may be necessary under the federal acts to pay them the value of their claims in cash, but if two-thirds of any class have agreed to the plan of reorganization, dissenters will be bound.

The other problems of reorganization growing out of the central problem of an economically sound and fair plan have not been solved by the developments in reorganization practice during the depression in the United States. Some steps have been taken towards their solution, however, and proposed legislation now before Congress may do much to solve some of the difficulties.

One problem which remains unsolved is the relative position which security holders should occupy after the reorganization has been effected. On one theory secured creditors are entitled to absolute payment before unsecured creditors are admitted. ${ }^{328}$ A somewhat opposite theory holds that all creditors are entitled to a maintenance of their relative positions; $;^{329}$ so that all creditors will be entitled to representation in the reorganized company, with the prior creditors having the prior right to income. In practice neither theory has been completely adopted. The situation has been complicated by the theory that stockholders are in a sense the debtor, and that to allow stockholders to participate before creditors are paid in full smacks of a fraudulent conveyance..$^{330}$ On the

${ }^{328}$ Frank, Some Realistic Reflections on Some Aspects of Corporate Reorganization r9 Va. L. Rev. 698 (r933).

${ }^{329}$ Swaine, Reorganization of Corporations: Certain Developments of the Last Decade, - 27 Col. L. Rev. 9or (I927).

${ }^{330}$ See Frank's "Farmer Smooth" illustration in Ig Va. L. Rev. 54I (I933). 
other hand, it is well known that under modern business conditions, stockholders are investors just as bondholders are, and that a division which places stockholders into the class of owners as opposed to creditors is slightly unrealistic. ${ }^{3{ }^{3 x}}$ Further, as the reorganization process has grown up stockholders are likely to have great control over the proceedings. In depression times there was sympathy for stockholders, equally if not more than for bondholders; and the theory that stockholders, more than any other class, would be willing to give new money as the price of their participation also increased the stockholders' power over the plan of reorganization.

The problem of the relative position which security holders should occupy has never been squarely faced. Probably the theory that secured claims must be first paid off in full is the dominant notion, modified, it is said, by practical conditions..$^{332}$ Practical conditions required the introduction of stockholders, and the Boyd case required that intermediate classes be allowed to participate. The result then began to support a relative priority theory, but the amount of priority, which in dollars and cents was the important question, was never decided. During the depression, however, stockholders did not contribute cash assessments. Save for their nuisance value, stockholders would have no right to participate in the reorganization of an insolvent corporation (insolvent in the bankruptcy sense), if the theory of absolute payment to secured claimants were accepted. Nevertheless the reorganization acts are drawn so that while it is possible to omit stockholders entirely if the debtor is insolvent, $^{333}$ nevertheless there is no requirement that this be done; indeed, under the reorganization acts it was first argued that in no case might stockholders be entirely eliminated. ${ }^{334}$

The sacrosanct position which secured creditors occupy is due to the remedy of which they are supposedly deprived. If secured creditors have a right to have their security sold to pay their claims, then obviously creditors with secured claims should be able to insist that no one else participate in the security until the secured creditors are paid. ${ }^{335}$ It was this idea which found expression in the composition section of the bank-

33r Isaacs, Business Security and Legal Security, 37 Harv. L. Rev. 20r (I923).

${ }^{332}$ Bonbright and Bergerman, Two Rival Theories of Priority Rights of Security Holders on Reorganization, 28 Col. L. Rev. I27 (1928).

${ }^{333}$ In re 620 Church Street Building Corporation, 57 S. Ct. 88 (I936) (insolvent in the bankruptcy sense).

${ }^{334}$ See In re Reading Hotel Corporation, Io F. Supp. 470 (Pa. 1935).

335 See Tennessee Publishing Co. v. American Nat. Bank, 57 S. Ct. 85 (I936). 
ruptcy act prior to the depression. That section did not affect secured claims at all. And it is the same notion which says that if there is a judicial sale of the security free and clear of the lien of the creditor, then the lien should attach to the proceeds. The absolute theory of priority is the inevitable result. The theory, however, is entirely unrealistic in the reorganization of a large company. Here the secured creditor only formally forecloses. Once it is admitted that the proceeding is primarily a reorganization proceeding, and that it is always that, it becomes strange to talk of depriving a secured creditor of a right which he never exercises. The only right the secured creditor has is the right to participate in the plan of reorganization. The participation that the secured creditor should have cannot be determined by the right that he would have if there were no reorganization. Such a procedure is a reference to a nonexistent right, since there is always a reorganization.

The confusion over the position the secured creditor should occupy is great. Section 74, the first depression arrangement statute, allowed secured claims to be extended but not reduced. In practical effect, an extension is a reduction, and it is difficult to find a theoretical justification for one and not the other. The inability to reduce secured claims by anything other than an extension seriously impaired the usefulness of section 74. It is therefore somewhat strange to find that in the proposed revision of the bankruptcy act now before congress, Chapter XI, which is in lieu of sections I2 and 74, appears without any provision for either the reduction or extension of secured claims. ${ }^{336}$ The revision now proposed, therefore, so far as section 74 is concerned, has adopted the theory that secured claims are sacrosanct and entitled to be paid off completely before other claims may be paid. On the other hand, the proposed revision has a special chapter dealing with real estate mortgages, ${ }^{337}$ and that chapter, which is applicable only to unincorporated debtors, allows secured claims to be reduced, and apparently makes only incidental provision for unsecured claims which, however, may also be reduced if two-thirds of the class accept. It is extremely difficult to find any justification for the position that secured claims may be reduced under the new Chapter XII, but that they may not be reduced under Chapter XI. And if the justification is that Chapter XI is intended for only mildly afflicted debtors, and

${ }^{33^{6}}$ Chapter XI of H.R. 8046, the proposed revision of the Bankruptcy Act, commonly known as the Chandler Bill. Chapter XI is of more importance than section 74 is, because under proposed Chapter $\mathrm{X}$, which takes the place of $77 \mathrm{~B}$, a petition must state "the specific facts showing .... why adequate relief cannot be obtained under Chapter XI of this Act." (Sec. 130).

337 Chapter XII. 
hence secured claims be not reduced, it is yet difficult to know why the rights of stockholders may not be changed under that chapter.

Sections 77 and $77^{B}$ of the bankruptcy act passed during the depression allowed the reduction of secured claims. But the position which claimants were to occupy in the proposed plan of reorganization was not made clear in the statute. It is probable that any plan which preserved the relative position of the classes and has won the two-thirds approval of the secured class, no unusual factors being present, would be considered a fair plan. But where the plan has not won the two-thirds approval of the secured class, it has been suggested that the plan which does not pay off secured claimants in full will either be an unfair plan, or, if fair under the act, that the act is unconstitutional since it takes away the security of the secured creditors without due process of law..$^{38}$ Such a view is tenable, however, only on two grounds. The first ground would be that secured creditors are entitled to payment in full before anyone else is paid. But the acceptance of that ground would mean that even if twothirds of the secured creditors approved the plan, the plan would be unfair or unconstitutional as to the remaining one-third. The second ground would have to hold that secured claims may be reduced only if two-thirds of the holders agree to the reduction. But it is difficult to see what magic lies in the two-thirds number. Indeed, section 74 allowed an extension of secured claims when there was only a bare majority in number and amount of all claimants, which might mean less than a majority of secured claimants. But, of course, in this respect section 74 might be unconstitutional. Nevertheless the question remains. Suppose a majority of secured creditors do approve, but forty per cent of the secured creditors are opposed. Upon what basis can it be said that plan is either automatically unfair or unconstitutional?

The problem as to what position stockholders, unsecured creditors, and secured creditors of differing rank should occupy in the reorganized company presents a problem to which an answer will only set the outer limits of a fair plan. It may well be that it is impossible to determine by rule the participation which should be allowed these groups in every case. It may well be that a rule of thumb should be established which will say, for instance, that secured creditors may not be reduced if two-thirds of them do not consent to the reduction. Such a rule would be based on

${ }^{33^{8}}$ See Matter of Tennessee Publishing Co., 8I F. (2d) 463 (C.C.A. 6th, I936), aff'd 57 S. Ct. 85 (I936), commented on in 34 Mich. L. Rev. I20I (I936), 35 Mich. L. Rev. 654 (I937); Dodd, Reorganization Through Bankruptcy: A Remedy For What?, 48 Harv. L. Rev. Iroo. II32 (I935). 
the idea that in most cases a plan which reduced secured claimants and did not win their two-thirds approval would be an unfair plan, and also partially on the idea that there is no absolute way of determining fairness, that fairness to a certain extent is a matter of majority rule. Whether the majority be placed at two-thirds or at a bare majority is a matter of expedience. It seems unfortunate to talk the language of unconstitutionality. But it is clear that the two-thirds requirement is not the whole story, for it should be noticed that a determination that creditors may be reduced if two-thirds consent, is not a determination that all plans which do this and have a two-thirds consent are fair. All that we have is a determination that majority consent is one factor in determining fairness. And it should also be remembered that junior lienholders may be omitted from the reorganization if it is clear that they have no equity, and that no claimants inferior to them are permitted participation even though all of the junior lienholders oppose their exclusion. ${ }^{339}$

But if majority consent is one factor in determining fairness, and perhaps the most tangible factor, then it must be assumed that the majority vote of each class participating, from whom a majority vote is required, represents the genuine desire of the majority. It must be a real election. The business situation is such, however, that it is very difficult to obtain a real election.

Writers on reorganization refer to the "masterful" position of the committee. ${ }^{34^{\circ}}$ From a business standpoint the masterful position is really that of the house of issue. It is the house of issue which is usually connected with the trustees under the indentures. It is usually connected with the agent for the debtor with whom funds for the payment of interest, principal, or sinking funds are deposited. The house of issue usually has some control over the debtor because it is the debtor's banker; it may be the necessary underwriter for new issues of the debtor. As the financial institution most closely related to the debtor, it is only natural that the house of issue should make loans to the debtor. When reorganization comes, it is usually the house of issue which organizes the committees for the security holders. In a certain sense, also, the house of issue has control over the investors who often bought their securities because of the reputation, advertising, or advice of the house of issue. The house of issue with its control over the trustees, the lists of security holders, the paying agent, the debtor, the committees, and the investors plays a dominant role in

339 See note $26 \mathrm{I}$ supra.

340 See Katz, Protection of Minority Bondholders, 3 Univ. Chi. L. Rev. 5I7, 52I (I936). 
reorganization even though it is not a formal party to the reorganization proceedings.

The control which the house of issue may exercise is easily illustrated. The house of issue through its control over the trustee can often regulate the declaration of a default and the acceleration of the mortgage. It may thus control the time when reorganization proceedings are to begin. Under most indentures, a stated number of the security holders may compel action by the trustee, but the security holders may not know of the default; they will not know each other so that it will be hard for the required number to join together. Even with the required number making a request upon the trustee, action may be delayed if the trustee asks for indemnity for the costs of any steps it will have to take. Meanwhile the house of issue with its control over the lists of security holders may organize its own committees and begin soliciting deposits. Any rival committee will be hampered because it does not have a list of security holders; it does not have the prestige of the house of issue; and the house of issue which has been able to begin organizing first will now be in a position to hurry the reorganization proceedings through its control over the trustee. Security holders who have deposited with the house of issue's committee may, of course, withdraw, but only on the payment of a cash assessment.

The house of issue through its control over the trustee and the paying agent may prevent defaults in the payment of interest from becoming known by advancing the money for such payments itself. Such advance-. ments may be made because of the charitable inclinations of the house of issue; more often not. Concealing a default in this manner allows the house of issue to empty its shelves of any hitherto unsold securities of the issue. ${ }^{34 \mathrm{x}}$ Because of its advancements the house of issue becomes a creditor of the debtor, if it already is not. The claim which it has is arguably on a par with the claims of bondholders, perhaps better, but in any case it can be liquidated by the acceptance by the house of issue of a second mortgage on the debtor's property. When this mortgage is forreclosed, the house of issue emerges as the owner of the equity. As the equity owner, or as a creditor in any capacity, the house of issue is deeply interested in the plan of reorganization. It is interested anyway because it gains power by control over the board of directors of the new company, for which it expects to act as banker. It can gain this control by desig-

${ }^{34}$ See Report on the Study and Investigation of the Work, Activities, Personnel and Functions of Protective and Reorganization Committees by the Security and Exchange Commission (Part III, I936) r7. 
nating the voting trustees for the stockholders of the new company, or by aiding in the selection of the new directors. The plan which the house of issue proposes through its committees can be aided by the inaction of the trustees under the indentures, or directly by the active aid of the trustees in favoring the plan, or indirectly through letters sent to security holders. If the house of issue is in any doubt as to its ability to collect debts owed to it by the debtor in the plan of reorganization, it may be able to use its control over the trustee to permit substitution of collateral under the indenture in order to free assets of the debtor from which the house of issue may collect its debt. By delaying foreclosure or the trustee's intervention in a pending receivership proceeding, it can keep rents and profits from inuring to the benefit of the security holders.

A committee chosen by the house of issue to represent security holders may actually attempt to work out a plan of reorganization in line with the best interest of the security holders. The reputation of the house of issue is said to be at stake. But a house of "interest" whose interests conflict with the security holders its committee represents is in the position of an arbiter of its own claims and hopes for the future. Further when the house of issue has organized many committees to represent security holders who have interests adverse to each other it is difficult to expect these committees, answerable to the same institution, to work at cross purposes.

The house of issue, however, is not the only villain of the piece. A - dying corporation attracts many kinds of people, some, but not all, philanthropically inclined. Outsiders, owning no securities or very few, may organize committees which will gain sufficient deposits to become either masters of the situation or at least to have a considerable bargaining power. An outside group, whatever its original motives may be, will soon see the possibility of controlling the revised corporation. ${ }^{342}$ The house of issue may be destroyed as a factor in the new corporation, but a new house of-issue is substituted in its place. This may be justified on the theory that the spoils of reorganization should not stay in one place for too long a time. It is doubtful whether it can be justified on the theory that security holders gain better representation.

The fact that security holders are not adequately represented by their committees is in part the fault of the security holders. The democratic process always requires responsibility and intelligence on the part of the

${ }^{342}$ As for instance the Fortington Group in the reorganization of Paramount Publix Corporation. See Report on the Study and Investigation of the Work, Activities, Personnel and Functions of Protective and Reorganization Committees by the Security and Exchange Commission (Part I, r937), r2. 
voters. It may be that the only answer to this portion of the problem is the greater education of security holders. Organizations for the education of security holders, it has been suggested, might perform a useful function..$^{343}$ Section 77 of the bankruptcy act dealing with railroad reorganization tried to meet this problem in two ways. (I) It required the Interstate Commerce Commission and the court to pass on the fairness of the plan before the plan was submitted to the vote of the security holders. This prevents the court from approving a plan of reorganization merely because security holders have already apparently approved it. This limits the democratic process and assumes that the court or the Interstate Commerce Commission can recognize fairness or unfairness in a way which the security holders cannot. (2) Section 77 also outlaws committees, save those composed of only twenty-five security holders, without the approval of the Interstate Commerce Commission. ${ }^{343 \mathrm{a}}$ But it does not indicate what rules the commission is to make for proper committees, and it gives the large institutional investors an advantage in that they may organize into groups of twenty-five and have great power. Section 77 also gives the court the power to ignore security holders' votes against a plan when it believes those votes not to have been "reasonably justified."

Section $77 \mathrm{~B}$ on the other hand retained the old procedure of having security holders vote first, although it, together with section 77 , gives the court power to pass on deposit agreements and to ignore any unfair provisions, and the effect of the Securities Act has been to promote deposit agreements which do not attempt to bind depositors to an unannounced plan.

A further difficulty with the democratic process as applied to reorganizations is that the interests of all the voters are not the same. The division into classes for the purposes of voting has never been clearly defined. The house of issue owning a claim as an unsecured creditor possibly ought to be treated differently either in the plan of reorganization or in the voting than other unsecured creditors. Its treatment on voting would not necessarily be dependent upon its treatment in the plan. But at present it is impossible to tell upon what basis a division into classes for the purpose of voting is to be made.

The economic and fair plan which is the object of reorganization apparently is something more than the proper exercise of the democratic

${ }^{343}$ This is the thesis of Reis, False Security (I937).

${ }^{343 \mathrm{a}}$ Note the protective committee for the first and refunding mortgage and certain debenture securities allowed by the Commission in the reorganization of the New York, New Haven and Hartford Railroad Co., New York Times, Jan. I6, I938, Financial Sec., p. I. 
process among security holders. The reorganization acts all require the court to find the plan fair and feasible. Indeed the tendency is clearly towards having the court exercise its judgment quite apart from whatever wishes the security holders may have expressed. This assumes that the court will be able to know a fair and feasible plan when it sees one. But the reorganization acts do not instruct the court.

An economically wise and a fair plan would seem to contain the following things: ( $\mathrm{I}$ ) the relative priority between the classes of security holders should be maintained as a minimum, while in cases of extreme insolvency, the complete elimination of stockholders or creditors of a lower order is possible; it would usually be better to permit participation, even though the right given may only be a right to purchase stock; $(2)$ the removal of inefficient management, the punishment of fraudulent management; (3) a capital structure which will not mislead security holders and will allow the new corporation to operate most efficiently; (4) the direction of the activities of the new company into economically sound fields. The result of such a plan will be that security holders, having been allowed to vote, and having had their rank preserved will feel satisfied. The future of the new company of course depends on efficient management. For the sake of the new company, both by way of revenue and example, fraudulent old management ought to be disgraced and sued. In order to provide sufficient cash leaway for operation and to prevent untimely defaults, the new capital structure should be molded to the demands of the new company. Its securities ought not to be misleading, if the democratic process in investments is to be made intelligible. This would eliminate debentures with negative pledge clauses of doubtful validity. While the future direction of the company may be left to an able management, the reorganization period ought to expose uneconomic activities which may be eliminated.

The reorganization acts have only partially placed the problem of the fair plan in this light before the court. It may be assumed that in general the relative priority will be maintained in any plan found to be fair by a court. But this is a minimum requirement and an admission that a plan which meets this minimum requirement should be the result of a struggle between classes fairly fought. This means that security holders must be made active and must be fairly represented. Section $77 \mathrm{~B}$ does little to promote their activity and fair representation. Section 77 which deprives security holders of the right to solicit and vote until the plan has been passed upon by the court would seem to dampen the enthusiasm of security holders. The ability of security holders to be heard during 
the proceedings is helpful. The ability of the court to gain the list of security holders from the house of issue under section 77 weakens the house of issue's dominant position and makes for fairer representation. Section 77 in making the appointment of a trustee mandatory, and in prescribing trustee qualifications has done much towards the discovery of previous fraudulent practices on the part of management, ${ }^{344}$ and should often lead to the removal of the old, and the installation of more efficient, management. But the appointment of a trustee is not mandatory under section $77 \mathrm{~B}$. Further, under section 77 , the Interstate Commerce Commission is also required to find that the plan is compatible with the public interest. This should include a wise capital structure, and one not misleading to security holders. But there are no similar requirements in section $77 \mathrm{~B}$.

The problems of reorganization may be thought to be in part insoluble. Perhaps they may be resolved only by treating reorganization as basically a struggle between conflicting interests. In a world in which the competitive system exists to some extent throughout the whole economic order, it would be naïve, perhaps, to assume, that competition can be avoided in a matter so essentially a part of the economic order as the rehabilitation of debtors and the protection of creditors, stockholders and outsiders in their scramble for what is, in a sense, a pirates' treasure washed up on the shore. But throughout the whole economic order, it is increasingly recognized that there is such a thing as fair and unfair competition. Make the competition fair,-that is the problem of those who would attempt to better reorganization practices. Apparently such was the aim of the framers of the Chandler ${ }^{345}$ the Lea ${ }^{346}$ and the Barkley bills. ${ }^{347}$

The Chandler Bill attempts to deal with straight bankruptcy and reorganization. The latter problem is handled in three chapters of the proposed revision of the bankruptcy act. Chapter $\mathrm{X}$ deals with corporate reorganization and is thus a rewritten section $77 \mathrm{~B}$. Chapter XI deals with arrangements and is the section $\mathrm{I} 2$ of the present bankruptcy act, dealing

${ }^{344}$ See 47 Yale L. J. 285 (1937).

345 H.R. 8046. This was introduced on July 28, 1937. An earlier draft, H.R. 6439, was introduced on April 15, 1937. Prior to that, there had been two earlier drafts, H.R. I2889, on which there were amendments proposed by the National Bankruptcy Conference, introduced May 28, x936, and H.R. I0382, on which hearings were held in March and April, x936.

${ }_{34} 4$ H.R. 6968, Committee Print No. 2, July 29, 1937 . This is a revision of the Bill as introduced on May II, 1937 .

347 S. 2344, Committee Print No. 3, June 29, I937, printed in Regulation of Sale of Securities, Hearing Before a Subcommittee of the Committee on Banking and Currency, United States Senate, page I96. There were two prior Committee prints: Committee Print No. I, May 6, 1927, Committee Print No. 2, June Io, 1937. 
with compositions, and section 74, dealing with the reorganization of individual debtors, rewritten. Chapter XII deals with real property arrangements, of unincorporated debtors, and as such is entirely new, although, as will be seen, it is a combination of the present section 74 with some of the aspects of $77 \mathrm{~B}$. There is, in addition, a fourth chapter, which, however, deals with the special problem of wage earners' plans. The Chandler Bill does not affect present sections 77, railroad reorganization, 75 , agricultural compositions and extensions, and $81,82,83$ and 84 , municipal debt readjustment.

Section ${ }_{77} \mathrm{~B}$ is recast very much along the lines of section 77 . The appointment of a disinterested trustee will be mandatory if the certain indebtedness of the debtor is $\$ 250,000$ or more, ${ }^{348}$ the court will pass upon the plan before security holders vote ${ }^{349}$ and before committees are allowed to solicit deposits. ${ }^{350}$ Committees representing more than twelve security holders are required to file statements, which are to include a copy of the deposit agreement, the history of the organization of the committee, a statement of the securities owned by the organizing institution or person behind the committee, and the claims of the committee members. ${ }^{35 x}$ Before security holders may vote on the plan, the plan must be submitted to the Securities and Exchange Commission for a report if the debtor has an indebtedness in excess of $\$ 3,000,000$, and may be submitted if the indebtedness is less. ${ }^{352}$ The plan when submitted to security holders has with it the report of the Commission, if any report is made. ${ }^{353}$ This provision differs from section 77 in that the report of the Securities and Exchange Commission is only advisory ; 354 it will serve to clarify the issues on which security holders are voting. The plan itself is to be drawn up by the trustee if a trustee is appointed. ${ }^{355}$ In this respect the proposed chapter is entirely different than any of the other federal reorganization acts. In those cases where the appointment of a trustee is not mandatory and the debtor is continued in possession, plans may be filed by ( $\mathrm{r}$ ) the debtor, (2) any creditor or indenture trustee, (3) any stockholder, if the debtor is not found to be insolvent, (4) a disinterested person who has

${ }^{34^{8}} \S$ I $5^{6}$ of H.R. 8046 hereafter referred to às "Chandler Bill."

$349 \S \mathrm{I} 74$; for confirmation of plan see $\S 22 \mathrm{I}$.

350 § I76. $\quad 35 \mathrm{I}$ \& $2 \mathrm{I2}$.

${ }_{352} \S$ I72. The S.E.C. is given broad powers as to notice and hearing. See $\$ \S 265,208,173$, $16 \mathrm{r}$.

$353 \S \mp 75(3)$.

$355 \S \mathrm{I} 69$. An examiner may be appointed, where the debtor is continued in possession, to prepare a plan, report on the debtor, examine witnesses, etc. See $\$ ₫$ I68, r6\%. 
been appointed by the court as examiner to prepare and file a plan. ${ }^{356}$ The chapter as found in an earlier draft, required a sinking fund or some other method for the retirement of obligations with a maturity of more than five years; this is now only discretionary. ${ }^{357}$ The chapter also gives greater power to the indenture trustee for representation of security holders. ${ }^{358}$

The proposed section increases to $\$ 5000$ the amount of claims which three creditors must possess before they can file an involuntary petition, but it removes the requirement that this amount must be above the security held by them. ${ }^{359}$ It also allows creditors of the debtor's property to file. It retains the requirement that petitioning creditors must either prove an act of bankruptcy or the pendency of a bankruptcy proceeding or equity receivership..$^{360}$ But it clarifies bankruptcy proceeding to mean where the debtor was adjudged a bankrupt, ${ }^{36 x}$ and it broadens the meaning of equity receivership to include the appointment of a receiver in a foreclosure proceeding and to include a trustee in possession under an indenture..$^{362}$ Insolvency either in the bankruptcy or equity sense is preserved as the basis of jurisdiction in any case. ${ }^{363}$ The act broadens the powers of the court to obtain the lists of security holders; to impound such lists; and to open them for inspection upon such terms as it may prescribe, ${ }^{364}$ thus adapting devices developed in receivership proceedings by Judges Lockwood and Mack. The qualifications for trustee are more stringent than those under section 77 . They are calculated to separate the trustee from the debtor, stockholders, creditors, and underwriters. ${ }^{365}$

356 § 770 . $\quad 357 \S 236$ (9).

$35^{8}$ See $\S$ I26 (file petition), $\S$ I44 (file answer), $\S$ I70 (may prepare plan), $\S$ I98 (may file claims), $\$ 242$ (specific provision for compensation). There are various provisions requiring notice to the indenture trustee. $\S \S 190,178, I 7 I, 247$. See also $\delta \S 166,197,206,207$. The court likewise has greater control over the trustee under the indenture. See $\$ \S 227,213,212$, 2II.

359 The claims must be "liquidated as to amount and not contingent as to liability." An indenture trustee may file a petition without other creditors joining with him. $\S$ I 26 .

${ }_{360} \S \mathrm{I}_{3} \mathrm{x}(\mathrm{I})$ and $(2) . \quad 36 \mathrm{I} \S \mathrm{r} 3 \mathrm{I}(\mathrm{I})$.

${ }^{362} \S \mathrm{I} 3 \mathrm{I}(3)$, and (4). This last subdivision provides: "that a proceeding to foreclose a mortgage or to enforce a lien against all or the greater part of the property of the corporation is pending."

${ }_{363} \S I_{3} \mathrm{O}(\mathrm{I})$. Every petition must give "the status of any plan of reorganization, readjustment, or liquidation affecting the property of the corporation, pending either in connection with or without any judicial proceeding." $\$ \mathrm{I}_{3} \mathrm{O}(6)$.

$364 \$ \$ 164,165,166$.

${ }_{365} \S 158$. The trustee may not be a creditor or stockholder, or underwriter of outstanding securities, or within 5 years have been the underwriter of any securities of the debtor. He may 
The act requires the plan to include provisions as to the selection of the new directors and any voting trustees. ${ }^{36}$ The court's jurisdiction over fees is somewhat broader than at present and a specific provision requires that no compensation or reimbursement be given to a committee, attorney, or other person, acting in a representative or fiduciary character, who bought or sold claims or shares of stock after the proceedings began. ${ }^{367}$

The proposed recasting of section $77^{\mathrm{B}}$ thus clarifies the present section to meet many of the objections made by courts, and it adopts the advances made by the present amended section 77 . It may be expected that the court will gain greater control over the plan of reorganization through its control over a disinterested and active trustee. But it may be questioned whether the effect of having the trustee draw up the plan of reorganization is wholly to the good. No plan can be satisfactory to all elements. It is sometimes desirable to allow these elements to propose their own plans first, and then through the ensuing struggle work out a compromise. The position of the Securities and Exchange Commission would seem very advantageous to such an end. But once the security holders feel that the plan upon which the Commission comments is not their plan, they are likely to be dissatisfied. This may be partially corrected by allowing all security holders to present suggestions to the trustee. ${ }^{68}$ It might have been better for the court to appoint a representative for each major class of security holder when the investments are sufficiently large.

Chapter X differs from old section 74, which it displaces, in that it

not be or have been within two years a director, officer, employee, or attorney of the debtor or underwriter. These prohibitions also apply to the attorney for the trustee except in special cases. $\S$ I57.

$366 \S 220(\mathrm{II}) ; \S 22 \mathrm{I}(5)$.

367 § 249. [The April $\Upsilon_{5}$ draft of the Chandler Bill, H.R. 6439, included "in contemplation of such proceeding." $\$ \mathrm{I} 2, \Pi \mathrm{II}$ e(9).] See $\$ \S 242$ to $25^{\circ}$ for the fee provisions. $\$ \S 244$ and $25^{8}$ deal with the problem of compensation for services rendered in prior proceedings.

Note the Act of August 25, I937, 28 U.S.C.A. $\$ 572$ A, which provides in part that "it shall be unlawful for any party in interest or any attorney for any party in interest, in receivership, bankruptcy, or reorganization proceeding, in or under the supervision of any court of the United States, to enter into any agreement, written or oral, express or implied, with any other party in interest, or any attorney of any other party in interest, in such proceeding for the purpose of fixing the amount of the fees or other compensation to be paid to any party in interest, or any attorney of any party in interest." Section b provides that it shall be unlawful for the judge to approve the payment of a fee set by an unlawful agreement. It is not clear what effect this Act will have on agreements to have the fee set by an impartial arbiter, such as the Securities and Exchange Commission.

${ }^{368} \S I 67(6)$ : The trustee "shall give notice to the creditors and stockholders that they may submit to him suggestions for the formulation of a plan, or proposals in the form of plans, within a time therein named." See also $\$$ I69. 
is now applicable to corporations, and in that secured claims may not even be extended. ${ }^{369}$ The only one who may submit a plan under Chapter $\mathrm{XI}$ is the debtor. This is somewhat anomalous in that Chapter XI, old section $77 \mathrm{~B}$, tends to take away from the debtor the power to propose a plan. ${ }^{370}$ Moreover, there is no indication under Chapter XI of how stockholders are to operate and whether they shall vote on the proposed plan which the debtor submits. The plan to be proposed does not include a change in the rights of stockholders, ${ }^{37 \mathrm{I}}$ although it seems that any complete readjustment, even if it did not affect secured claims might well effect such a change. Unlike old section 74, proposed Chapter XI does authorize class voting, but apparently the division into classes must be based on the treatment accorded creditors in the plan. ${ }^{372}$ The section does not mention committees nor trustees under indentures, even though both of these exist for unsecured creditors. ${ }^{373}$ The appointment of a receiver is still not mandatory. ${ }^{374}$ While the court is to pass on the fairness of the plan, ${ }^{375}$ the section has a provision which might be interpreted to make court approval automatic if all the unsecured creditors agree to the readjustment. ${ }^{376}$ Before a petition under Chapter $\mathrm{X}$ (old section $77 \mathrm{~B}$ ) may be filed in good faith it will have to be shown that adequate relief could not be obtained under Chapter XI. ${ }^{377}$ On the other hand, there is no longer any good faith requirement under Chapter XI. ${ }^{378}$ An additional peculiarity of Chapter XI is that only claims provided for in the plan

${ }_{369} \S 306(\mathrm{x})$ : " 'Arrangement' shall mean any plan of a debtor for the settlement, satisfaction, or extension of the time of payment of his unsecured debts, upon any terms. . ..."

${ }^{370}$ And, furthermore, the first draft of the Lea Bill, H.R. 6468 , provided in $\S$ Ix that "A reorganization plan may be deemed to be improperly proposed .... (2) if any person who is directly or indirectly proposing such plan or causing the same to be proposed is the issuer. ...."

371 $§ 257$. $\quad 372 \S 35 \mathrm{I}$. "For the purpose of the arrangement and its acceptance."

${ }^{373}$ It does mention committees of creditors in $\$ \S 337(2), 338,327$, but the reference is to $\S 44 \mathrm{~b}$ which "provides for the appointment by the creditors at their first meeting of a committee of not less than three creditors to consult with and advise the trustee in connection with the administration of the estate." (Report No. 1409, 75th Cong. Ist Sess. (I937), II.).

374 $\$ 332$. Although if a trustee in bankruptcy has previously been appointed, the court must continue such trustee in possession.

$375 \S 366$.

${ }_{376} \S 36 \mathrm{x}$. The court must be satisfied that the arrangement and its acceptance are in good faith and have not been made or procured by any means, promises or acts forbidden by the Act. This is different, however, than a finding that the plan "is fair and equitable and feasible," required under $\$ 366(3)$.

$377 \S \pm 30(7)$. him.

${ }^{378} \S 323$. But the petition must set forth the provisions of the arrangement proposed by 
are to be discharged, ${ }^{379}$ but it is also provided that the plan is to be binding on all claims whether they are provided for in the plan or not. ${ }^{380}$ This seems to be clearly an error in draftsmanship. ${ }^{38 x}$ The act requires the deposit of money necessary to pay all debts having priority before confirmation of the plan..$^{82}$

Chapter XII is applicable to holdings of real estate or chattels real; it allows secured obligations to be altered or modified..$^{38}$ It is only applicable to unincorporated debtors and the arrangement which may be proposed must modify the rights of secured creditors $3^{384}$ nevertheless the definition of creditors includes unsecured creditors, ${ }^{385}$ and the arrangement "may provide for treatment of unsecured debts on a parity one with the other, or for the division of such debts into classes and the treatment thereof in different ways or upon different terms." 386 The chapter fails to define what is a real estate or chattel real holding for its purposes. Otherwise the chapter generally follows the pattern set by the present section $77 \mathrm{~B}$, except that the creditors may not file a petition. ${ }^{387}$ The debtor is required to propose an arrangement in his petition. ${ }^{38}$ Creditors who have claims against the property may propose an arrangement, which has been accepted by 25 per centum in amount of some class of creditors and Io per centum in amount of the claims of all creditors. ${ }^{389}$ The court has control over fees; ${ }^{390}$ the appointment of a receiver is permissive. ${ }^{395}$

The proposed bankruptcy act also includes a Chapter XIII, under which wage earners may offer a plan of composition or extension to their creditors. The chapter does not affect claims secured by real estate or chattels real. ${ }^{392}$ It may not affect secured creditors unless they consent. ${ }^{393}$

$379 \$ 37$ I. $380 \S 367$.

${ }^{38}$ It may be possible to reconcile these provisions, but the provisions are not clear.

${ }^{882} \S \S 337(2), 3^{61}$.

${ }^{383} \S 406(r)$ " 'Arrangements' shall mean any plan altering or modifying the rights of creditors or of any class of them, holding debts secured by real property or a chattel real of which the debtor is the legal or equitable owner."

${ }^{8}{ }_{4}$ Ibid.

$3^{85} \S 406(5)$ and $(2)$. $\quad 387 \S 42 I$.

${ }^{386} \S 46 \mathrm{I}(3)$. $\quad{ }^{388} \S 423$.

${ }^{389} \S 466$. This section speaks of debts of creditors; obviously claims is intended.

$390 \$ \$ 49 \mathrm{I}, 492,493,494,495,496,497,498$.

$391 \S \S 432,437(\mathrm{r})$.

${ }^{392} \S 606(\mathrm{x})$.

$393 \S 652(\mathrm{I}) ; f f . \S 646(2)$, which is somewhat misleading in stating that a plan "may include provisions dealing with secured debts severally, upon any terms." 
It is puzzling to understand the psychology of the draftsmen who felt (I) that secured creditors of a corporation could not be dealt with under Chapter XI, but they might if the corporation is sufficiently sick to come under Chapter $\mathrm{X}$; (2) that secured creditors with claims against real property of an individual debtor could be scaled down, while secured creditors of a corporation which owns real property may not be scaled down, unless it can proceed under Chapter X; (3) that unsecured creditors of a corporation obliged to proceed under Chapter XI may have their claims reduced, but that no provision need be made for arranging claims of stockholders-the "sacredness" of security is turned topsy turvey; and (4) that an individual debtor may scale down claims against his real property, while a wage earner's rugged morality must be protected against such demoralizing arrangement practice. But, of course, they might believe that a debtor who is a freeholder ought to receive much kinder treatment than a mere wage earner.

Other legislation has been introduced in Congress which if enacted might result in more sweeping changes in reorganization practice than the revised Chandler Bill. In particular, the Committee Act of 1937,394 known as the Lea Bill, and the Trust Indenture Act of $1937,{ }^{395}$ known as the Barkley Bill, would do much to avoid the possibility of conflicting interests arising to mitigate the effectiveness of the representation of security holders by committees, or by trustees under indentures. The very presence of the Lea Bill is some indication that despite the provisions under Chapter $\mathrm{X}$ of the Chandler Bill forbidding the solicitation of acceptances or of authority to accept a plan, until after the entry of an order approving the plan, ${ }^{396}$ it is thought that committees will be in operation under that chapter. Arguments advanced against both the Lea and Barkley Bills are based on business expediency, and as a result of these arguments both bills have been materially modified, although apparently not sufficiently to satisfy their opponents. ${ }^{397}$

${ }^{394}$ H.R. 6968, July 29, I937, Committee Print No. 2. An addition then is H.R. 6963 which would give the Securities and Exchange Commission powers over committees, powers to intervene and to file reports in plans of reorganization.

${ }^{395}$ S. 2344, 75th Cong. Ist Sess., Committee Print No. 3, June 29, $x 937$, found in Fearing Before a Subcommittee of the Committee on Banking and Currency (I937) 196.

$396 \S$ I $_{7} 6$ of the Chandler Bill.

${ }^{397}$ See Hearing on H.R. 6968,1937, I 53 et seq. Note statement by G. S. Canright in Hearing on S. 2344, I937, I3I et seq.

The Committee of Administration of Bankruptcy Law of the Chicago Bar Association, after due deliberation and under the chairmanship of Mr. Benjamin Wham, has adopted a report of its subcommittee concerning the Lea Bill. Eleven specific objections are made to the Lea Bill: (I) the "language of the Bill is so broad that it may well be construed to include ordi- 
The Lea Bill would in effect give the Securities and Exchange Commission control over all committees soliciting deposits, which use any instrumentality of interstate commerce or the mails. Its provisions would do much to separate committees from the control of the house of issue or the debtor. It would require generally that members of committees own some of the securities of the class they represent and that they have no conflicting interests. In its original form the Lea Bill also included provisions which would have allowed the Securities and Exchange Commission to pass on plans of reorganization, and it was calculated to discourage debtor plans. There was also an attempt to require state courts to pass upon plans before they were submitted to security holders. These latter provisions have now been removed. The Lea Bill in its present form is not adequately correlated with the Chandler Bill, and revision along that line is no doubt necessary. ${ }^{398}$

The proposed Trust Indenture Act of $1937^{399}$ would ban the now usual exculpatory provisions from new indentures, impose active duties on trustees under indentures, in effect separate the trustee from the influence of the debtor or house of issue, limit the trustee's rights to be a creditor, and in general require the removal of a trustee having adverse interests. The act shows the influence of New York's Streit law.

nary business transactions not intended to be included by its draftsmen"; (2) the Bill does not define what ownership of securities will be considered to be beneficial ownership; (3) "by precluding the issuer and underwriter from taking any part in the solicitation of deposits the Bill has taken away the only effective way of securing prompt deposit of securities"; (4) the underwriters or its nominees, "officers and directors of issuers and common stockholders," should be allowed to take part in the solicitation of deposits; $(5)$ "it has often been necessary for protective committees to incur substantial expenses which could only be met through loans obtained by pledging deposited securities. Under the wording of this Bill, it is doubtful if committees organized underits provisions can so finance themselves"; (6) it is not practicable to require the filing of a copy of the proposed plan of reorganization; (7) all pending reorganizations should be exempted from provisions of this Bill; (8) "it would seem advisable, in the interest of expediency, to permit assents to be counted as at present where the holder fails to dissent within a stated period"; ( 9 ) the Bill will regulate matters in state courts and under state practices which vary and "we doubt whether or not this Bill could be conformed to such varied laws and practices"; (ro) the provisions should be revised to conform to the Chandler Bill; (II) "we are opposed to the giving to any politically constituted body the broad powers given by this Bill to the Securities \& Exchange Commission."

Possibly this committee will give further study to its report. For instance, Sec. 304(a)(2) of the Lea Bill includes, as an exempted solicitation, a solicitation in respect of a class of securities to which public solicitation was made prior to the sixtieth day after the enactment of the Bill.

${ }^{398}$ For instance the Lea Bill is applicable apparently only to Chapter X and not to Chapters $\mathrm{XI}$ and XII of the Chandler Bill.

${ }^{399}$ See note 395 silpra. 
It may thus be seen that the law of arrangements and reorganization has changed radically in the United States during the depression. It is still changing. At present the philosophy behind the acts is confused. Some sections are calculated to give the debtor control over the proceedings; others attempt to do the same for the creditor. It is becoming clear, however, that the object of an arrangement is an economically sound and fair plan. It is not at all clear what is meant by a fair plan. The acts show both a tendency to remove the vote of the security holders as an important part in the determination of fairness, and a tendency to strengthen the representation of security holders so that when a vote is obtained it will reflect maturer judgment on the part of the security holders. Possibly the greatest stumbling block in the attempt to arrive at fair plans was the conflict of interest inherent in almost every reorganization agency. The proposed legislation will do much to eliminate this. The proposed Committee Act also shows an awareness that reorganization through the bankruptcy sections is merely a part of the larger problem of the reconstruction of debtors. If such an attitude prevails it will break down the artificial barriers which now exist between stockholder recapitalization problems, voluntary arrangements, and bankruptcy reorganization. It will certainly break down the barriers which the proposed revision of the bankruptcy act would impose. It may well lead to an understanding that the problem of reorganization is basically a problem of protection of credit. In the corporation field this can only be done by control over the original corporate structure. The new legislation already shows the desire of the framers to control the corporate structure after reorganization. This logically leads to control before reorganization. The simplification of the corporate structure can best be obtained through a corporation act. A federal corporation act may well be the coming answer. It may well be that self-imposed limitations on the bankruptcy power will disappear when it is understood that in the beginning of a corporation is its end. The reorganization sections may become simply federal debtor laws and federal incorporation acts. 